ばならないが胸部系においては 8～10倍の拡大は可能た ある. 抎大用のX線管加 $100 \mu \mathrm{m}$ 焦点 2 極管に移行しつ つあるが，我々の実験によれば，むしろ $50 \mu \mathrm{m} 3$ 極管あ るいは，それ以下のあのを開発して行くべきである。

\section{Greode1 氏効果による散乱線除去}

中央鉄道病院

$$
\begin{aligned}
& \text { ○大浅 勇一山山下 信夫・東浜 宏明 } \\
& \text { 佐々木 功・松田 陽一 }
\end{aligned}
$$

X線写真の画質に如いて，読影可能のラインを超える 写真を撮影すべきでない.とのととは，X線写真の画質 向上と被懪線量軽減とは相反関係にあるという点に立っ て言えることなのであるが，本実験で，グレーデル氏効 果を利用して，画質がベストの状態より悪化させ，その 分, 被曝線量はよ゙う変化するかというととを試みた。

画質は，MTF (contrast法) とコントラストを求めて 評価する之，高空間周波数側では，概ね同等であった。 被曝線量については，一例を述べると，ファントム厚20 $\mathrm{cm}, 60 \mathrm{kV}$ の条件で Airgap $10 \mathrm{~cm}$ と Grid 5: 1 を比較 すると, 前者は後者の約半分の被曝線量で, 撮影が可能 であった。

\section{座長集約}

ここの演題群は撮影時の像の形成に関与する種々の因 子（X線出力, 焦点, 散乱線, 拡大率) についての研究 が集まって和り，撮影ではすつとも重要視しなければな らない基礎研究である。最近ての種の演題が増加したて とは喜ばしい。

211 は演題100で発表された 3 相X線装置の短時間 $\mathrm{X}$ 線 特性に関連して単相単パルス特性を調べたすので，兩者 とも共通して短時聞撮影時の投入位相，遮断位相の調整 不十分がX線出打影響するととを指摘して扔り，現在 のX線装置で短時間撮影時の注意事項の一つになる.

212および213は同じ演者の発表で，各撮影条件でのX 線出力, X線減弱幽線について理論計算と実験データを 結びつける時の数学的な手法, 精度について論じたすの で，演者が解析に用いたデータ值はもともとばらつきの 入らない理論計算で得られたものであり，奏際の実験デ 一タは，ばらつきが多く入り込むため結果隹かなり状況 が異なると禇えられる。

214 《 2 種のX線装置で得られるX線の減弱曲線から 線量, 線質の関係を求める方法であるが, 線量, 線質は 減弱的線を求めた時点ですでにわかるもので，むしろ撮 影の条件，管球特性の真のずれにむすびつけた方が良い のではなからうか。
215はX線の焦点測定法としてピンホール法とチャー ト法の比較を行っている. あとすと，ピンホール法が X 線焦点の形を直接に実像として測定するのに対してチャ 一ト法はチャート像の解像能力から間接的と焦点の大き さを推定する委ので，評価基準が異なるため雨者を同一 次元で論ずるのは無理であり，相互関係を岁後研究して 頂きたい.

216および217は目的は異なるが共に拡大撮影について の研究であり，前者ば乳房撮影時の拡大撮影の有效性を 特にMo 管球と希土類螢光体，オルソフィル系について 述べられたが，国立名古屋病院の柴山氏より，W管球に ついてあ十分に撮影が可能とのコメントがあった．後者 の発表は焦点の大きさと拡大率の限界の実験であり，焦 点の他にX線出力, フイルム系の感度が関連するためと れらを総合した評価が必要になるだるう。更に拡大像そ れ自身は直接像とかなり違ったイメージを与えるので実 際の讋断には別の意味の最高值があるかす知れない。

218はグレーデル效果を格子等と比較したものである が，実験には照射野，管電圧，チャートの位置関係等多 くの因子が重なって作用するため，互いの相関関係を調 ベる必要がある。

との演題群は撮影の基礎となる重要な問題が多く，し かあ実験の裹付けとなる理論的な解析す必要とするため 今後上むなお一層の研究が待たれる。

\section{感光材料 1}

座長 四宮 恵次（大日本塗料）

\section{9. 高感度系感光材料の使用知見}

化学療法研究所附属病院

○林 太師

千葉大学放射線技師学校 酒井、尚信

\section{0．粒状性の濃度特性による希土類增感紙の評価}

ダイハッ保健センター 春田修

希土類增感紙共通の欠点は精状性の悪さに有る.との 荒について簡便で，しか专視覚評価に良く相関する評価

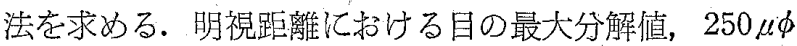
以上の高アパーチャで直接粒子を测定し，求まったデー 夕を視覚評洒の条件を考慮して，低濃度側のみの分散度 で示す．との值を平均濃度に対する粒子浱度幅の比で補 正した值を本報の評価值とする，本法にて G4 と LD を 比較すると， $\mathrm{D}=0.2 \sim 1.5$ までは LD が悪いがてれ以上 では差が無い事が解明出来た。しかも $\mathrm{D}=0.3 \sim 0.9$ の視 